\title{
CINSEL HEYECAN ARAMA ÖLÇEĞi (CHAÖ): TÜRKÇEYE UYARLAMA, GEÇERLIK VE GÜVENIRLIK ÇALIŞMASI ${ }^{1}$ \\ SEXUAL SENSATION SEEKING SCALE (SSSS): THE STUDY OF ADAPTATION TO TURKISH, VALIDITY AND RELIABILITY
}

Levent KIYLIOĞLU²

\section{ÖZET}

Cinsel heyecan arama bir model olarak ideal cinsel heyecan düzeyine ulaşma eğilimi ve yeni cinsel deneyimlerde bulunma olarak tanımlanır. Cinsel Heyecan Arama Ölçeği (CHAÖ)'nin Türkçe'ye uyarlamasının yapıldığı bu çalışmada, 183 üniversite öğrencisine CHAÖ'nin Türkçe'ye çevrilmiş hali, Cinsel Risk Alma Ölçeği ve Sosyal Beğenirlik Ölçeği uygulandı. Yapılan analizler sonucunda CHAÖ'nden alınan puanlar ile riskli cinsel davranışlar arasında orta düzeyde anlamlı bağıntılar bulunmuş olup, CHAÖ'nin tek boyutlu cinsel heyecan aramayı ölçtügü, cinsel davranışlarla ilişkili AIDS riskini ölçmede güvenilir ve geçerli görünen bir ölçme aracı olduğu sonuçlarına ulaşıldı.

Anahtar Sözcükler: AIDS, cinsel heyecan arama ölçeği, güvenirlik, geçerlik

\section{ABSTRACT}

The Sexual Sensation Seeking as a model defined as the propensity to attain optimal levels of sexual excitement and to engage in novel sexual excitement. In this adaptation study of the Sexual Sensation Seeking Scale (SSSS), one hundred eighty three university students completed Turkish translated form of the SSSS, Sexual Risk Taking Scale and Social Desirability Scale. As a result of the analysis it was found that scores of the SSSS moderately and significantly correlated with risky sexual behaviors, concluded that Turkish form of the SSSS measuring one dimensional sexual

${ }^{1}$ 3-6.Eylül.2014, 14th Biennial Conference of the European Association for Research on Adolescence, sözel bildiri olarak sunulmuştur

${ }^{2}$ Ankara Üniversitesi Sosyal Bilimler Enstitüsü Doktora Öğrencisi, levent.kiylioglu@gmail.com 
sensation seeking, reliable and appeared valid in order to measure AIDS risk that related to sexual behaviors.

Key Words: AIDS, sexual sensation seeking scale, reliability, validity

\section{GiRiş}

Kişilik özellikleri risk alma davranışıyla bağıntılı bulunmuştur. Bireyin risk alma davranışıyla ilişkili olduğu bildirilen heyecan arama düzeyi ilk olarak Zuckerman vd. (1964) tarafından ortaya atıldı. Zuckerman (2007) heyecan aramayı çeşitli, yeni, karmaşık ve yoğun heyecan ve deneyimler aramak, bu tür deneyimler uğruna fiziksel, sosyal, yasal ve parasal risk almaya istekli olmak şeklinde tanımlamıştır. Geleneksel olarak, heyecan arama; heyecan ve macera arayışı, deneyim arayışı, davranış üzerinde kontrolün azalması ve can sıkıntısına duyarlılık olmak üzere dört boyutta incelenir (Zuckerman, 2007).

Heyecan arayanlar yüksek duyusal uyarılma elde etmek için risk alırlar (Kalichman vd., 1996). Zuckerman (2007) heyecan aramayı genetik kaynağı olan, sabit bir kişilik özelliği olarak kabul eder. Ortalama heyecan arama düzeyi çocukluk döneminde artma eğiliminde olup, ergenliğin sonunda zirveye ulaşmakta ve yetişkinlikte düşme eğilimine girmektedir. Literatürde heyecan arama kişilik özelliği ile riskli araba kullanma, riskli spor yapma, riskli meslek tercih etme, madde bağımlılığı, riskli cinsel davranış, suç davranışı ve antisosyal davranış ile ilişki olduğu belirtilmektedir (Zuckerman, 2007).

İnsanı HIV (Human Immunodeficiency Virus - İnsan Bağışıklık Yetmezlik Virüsü) bulaşma riskine atan cinsel eylemler, heyecan aramanın yalnızca bir ifadesidir (Kalichman ve Rompa, 1995). Cinsel heyecan arama bir model olarak, ideal cinsel heyecan düzeyine ulaşma eğilimi ve yeni cinsel deneyimlerde bulunma olarak tanımlanır ve riskli cinsel davranışların heyecan arama kişilik özelliğinin bir ifadesi olduğunu öne sürer (Kalichman vd., 1994; Kalichman ve Rompa, 1995).

HIV'in temel bulaşma yolları cinsel davranışlar ve damar içi uyuşturucu madde kullanımıdır (Kalichman vd., 1994). Yakın bir gelecekte HIVIAIDS aşısı geliştirme umudu olmaması nedeniyle, yeni HIV bulaşmasını engellemenin tek umut verici yöntemi psikososyal müdahaleler olarak görünmektedir (Hendershot vd., 2007). 
Bir kişi ne kadar fazla cinsel yönden aktif ise ve ne kadar fazla kişiyle cinsel ilişkiye girerse, cinsel risk alma olasılığı o kadar artar (Bancrott vd. 2004). Farklı cinsel davranış örüntüleri riskli cinsel davranışı tanımlamak için kullanılır. Cinsel ilişkiye girilen kişi sayısı, cinsel ilişkilerde düzenli kondom kullanmama, vajinal ve anal cinsel ilişki sıklığı, tek gecelik cinsel ilişki sıklığı, çalışmalarda sıklıkla riskli cinsel davranışı ölçmede kullanılan sorulardır (Arnold vd., 2002; Gaither ve Selldom, 2003; Gullette ve Lyons, 2005). Cinsel aktif bireylerin düzenli ve doğru bir şekilde kondom kullanması, cinsel eylemleri HIV taşımayan birisiyle sınırlaması HIVIAIDS'ten korunmada en etkili yöntemler olarak gösterilmektedir (Hoyle vd., 2000).

AIDS Türkiye için önemli bir sağlık sorunu olma yolunda ilerlemektedir. Ülkemizde ticari seksin yaygın olduğu ve kondom kullanımının düşük seviyelerde olduğu belirtilmiştir (Nielsen ve Lazarus, 2006). Ay ve Karabey (2006) ülkemizde halkın genelinin ve hükümetlerin hasta sayısının düşük görünmesine yol açan eksik bildirimler nedeniyle HIVIAIDS'i öncelik olarak görmediklerini ifade etmişlerdir. Çok vd. (2001) ise, birçok ülkede HIVIAIDS korunma programlarında üniversite öğrencilerinin hedeflenmesine rağmen, Türk üniversite öğrencilerinin HIVIAIDS konusunda bilgi, tutum ve risk algıları ile ilgili bilgilerin sınırlı olduğunu, yapılan çalışmaların öncelikle HIVIAIDS ile ilgili olgusal bilgiye odaklandığını bildirmişlerdir.

Üniversite yıllarının birçok öğrenci için kişisel özgürlük ve çok sayıda yeni sosyal deneyim ve ilişkiler dönemi olduğu belirtildiğinden (Gullette ve Lyons, 2005), üniversite öğrencilerinin HIVIAIDS açısından risk altındaki gruplardan biri olduğu söylenebilir. Duyan (2006) ise, HIV enfeksiyonuna yakalanmayı, risk grupları olarak adlandırılan grupların bir üyesi olma ile ilgili olmadığını, riskli davranışları yapmanın bir sunucu olduğunu ifade etmiştir.

Ülkemizde cinsel heyecan arama düzeyini ölçen ya da AIDS riskine yol açan kişilik özelliklerini ölçen bir ölçme aracı bildiğimiz kadarıyla geliştirilmemiştir ya da yurtdışında geliştirilmiş ölçeklerden Türkçe'ye uyarlaması yapılmamıştır. Bireyde riskli cinsel davranışa yol açtığı bildirilen cinsel heyecan arama düzeyinin belirlenmesini sağlamak amacıyla bir değerlendirme aracı gerekli görünmektedir. Bu bulgu ve bilgilerden yola çıkarak bu çalışmada, Cinsel Heyecan Arama Ölçeği'nin Türkçeye uyarlaması ve psikometrik özelliklerinin saptanması amaçlanmıştır. 


\section{YÖNTEM}

\section{Katılımcılar}

Ankara ilindeki çeşitli üniversitelerde öğrenimlerine devam eden 75'i (\%41.0) kadın ve 108'i (\%59.0) erkek olmak üzere toplam 183 karşıt cinsel yönelimli, bekâr, cinsel aktif öğrenciye anket şeklinde hazırlanmış ölçek uygulaması yapıldı. Gönüllü katılımcılara araştırma uygulaması öncesinde çalışma hakkında bilgi verildi ve sözlü onamları alındı. Katılımcıların yaş aralığı $18-30$ arasında olmasına rağmen \%75'inin 19 ile 23 yaşları arasında oldukları görüldü. Katılımcıların büyük bir çoğunluğu (\%91.7) HIVIAIDS testi yaptırmadıklarını, HIVIAIDS testini yaptıranlar (\%9.3) ise virüsü taşımadıklarını belirtti. Sadece 10 katılımcı (\%5.5) cinsel yolla bulaşan başka bir hastalığa (hepatit, frengi gibi) hayatlarının bir döneminde maruz kaldıklarını bildirdi.

Katılımcıların \%54.6'sı üniversiteye başlamadan önce metropollerde, \%34.4'ü illerde, \%10.4'ü ilçelerde yaşadığını \%4.4'ü gelir düzeyini çok iyi, \%39.3'ü iyi, \%50.8'i orta, $\% 5.5^{\prime} \mathrm{i}$ ise kötü ya da çok kötü olarak belirtti. Diğer taraftan katılımcıların \%27.3'ü üniversitedeyken yurtta kaldığını, \%10.4'ü kendi başına evde, \%33.3'ü ailesiyle birlikte, \%27.3'ü ise arkadaşlarıyla evde ikamet ettiğini bildirdi.

\section{Veri Toplama Araçları}

Çalışmanın verileri "Demografik Veri Toplama Formu", "Cinsel Heyecan Arama Ölçeği", "Cinsel Risk Alma Ölçeği" ve "Sosyal Beğenirlik Ölçeği” kullanılarak toplanmıştır.

Cinsel Heyecan Arama Ölçeği (CHAÖ): Zuckerman'ın Heyecan Arama Ölçeğinin AIDS riskini yordamada sınırlı görünmesi nedeniyle, Kalichman vd. (1994) cinsel davranışa özel heyecan arama ölçeği geliştirdiler. Kalichman vd. (1994) eşcinsellerde AIDS risk davranışını yordamak için Zuckermen ve arkadaşlarının Heyecan Arama Ölçeğinin (1978) cinsellikle ilgili temaları yansıtan maddelerini değiştirerek 9 maddelik CHAÖ'ni geliştirdiler. Kalichman ve Rompa (1995) CHAÖ'ni eşcinsel örneklemin yanında, şehirlerde yaşayan düşük gelirli karşıt cinsel kadın ve erkek örnekleminde uyguladı ve karşıt cinsellere uyarlama çalışması yaptılar. Gaither ve Selldom (2003) ise ölçeğin karşıt cinsel üniversite öğrencileri örnekleminde geçerlik ve güvenirliğini araştırdı ve değerleri yeterli düzeyde buldu. 
Amerika Birleşik Devletleri'nde (A.B.D) geliştirilen bu ölçek, cinsel heyecan arama ile ilgili 11 maddeden oluşan dörtlü likert tipi bir ölçektir (Kalichman ve Rompa,1995). Ölçeğin puan dağıımı 11 ile 44 arasında olup, daha yüksek puanlar daha fazla cinsel heyecan arayışını göstermektedir. Ölçeğin A.B.D.'deki geliştirme çalışmasında iç tutarlılığı karşıt cinsel örneklemde 0.81 bulundu. Erkek ve kadınların CHAÖ'nde anlamlı bir şekilde ayrıştığı, erkeklerin kadınlardan daha yüksek ölçek puanı aldığı görüldü. Cinsel heyecan arama puanları ile korunmasız cinsel ilişki sıklığı ve cinsel ilişkiye girilen kişi sayısı arasındaki korelasyonlar anlamlı bulundu. Ayrıca CHAÖ'nin bir dizi güvenli cinsel davranışla da ilişkili olduğu görüldü. CHAÖ geliştirme çalışmalarında (Kalichman vd., 1994; Kalichman ve Rompa, 1995) ölçeğin, kusursuz güvenirlik ve yapı geçerliği bulgusu gösterdiği ve HIV bulaşma riskini anlamada yararlı bir yapı olduğunu ispatladığı bildirildi.

Cinsel Risk Alma Ölçeği: Cinsel heyecan arama kişilik özelliğinin AIDS riskine yol açan cinsel eylemleri yordadığı iddia edildiğinden, katılımcıların cinsel etkinliklerini ölçmek için aynı zamanda Cinsel Risk Alma Ölçeği uygulandı. Hırvatistan'da geliştirilmiş olan Cinsel Risk Alma Ölçeği (Stulhofer vd., 2009), kişinin son 12 ay içerisinde ve tüm hayatı boyunca yaşadığı riskli cinsel davranışları hakkındaki 10 maddeden oluşan ve çoğunlukla evet hayır şeklinde yanıtlanan bir değerlendirme aracıdır. Ölçeğin puan dağılımı 0 ile 10 arasında olup, daha yüksek puanlar daha yüksek riskli cinsel davranışa işaret etmektedir. Ölçeğin Hırvatistan'daki ilk uygulamasında ortalama cinsel risk puanı 3.45 , standart sapma 2.13 ve iç tutarlılık katsayısı 0.64 olarak bulundu.

Ölçeğin bu makalenin yazarı (yayınlanmamış ön inceleme, 2012) tarafından yapılan uyarlama çalışmasında, üniversite öğrencilerinden veri toplandı. 'Hiç cinsel ilişkiden önce alkol kullandınız mı?'maddesinin madde toplam korelasyonunun düşük çıkması nedeniyle maddenin yanıt anahtarındaki puanlamanın değiştirilmesine karar verildi. Ölçekteki toplam 10 maddenin alfa iç tutarlılık katsayısı değeri 0.71, iki yarım güvenirlik katsayısı 0.68, katılımcıların ortalama cinsel risk puanı ise 3.31 olarak bulundu. Erkek katılımcıların riskli cinsel davranış puanları kadın katıımcıların puanlarından anlamlı olarak daha yüksek bulundu ve bu sonuç literatürdeki bulgularla tutarlılık göstermektedir ( $\mathrm{t}=3.49$, df: 181, $p<.01)$. Ölçeğin ayırt edici geçerliğini sınamak için verilere t- testi uygulandı ve cinsel yolla bulaşan bir hastalık tanısı alanlarla 
almayanların riskli cinsel davranış puanları arasındaki farka bakıldı. Cinsel yolla bulaşan bir hastalık (hepatit, frengi gibi) tanısı alanların riskli cinsel davranış puanlarının tanı almayanlardan anlamlı olarak daha yüksek olduğu görüldü ( $t=3.52$, df: 181, $p<.001)$. Ayrıca ölçeğin sosyal beğenirlik kaygısından etkilenmediği sonucuna ulaşıldı.

Sosyal Beğenirlik Ölçeği: Katılımcıların ölçeklere verdikleri yanıtların sosyal beğenirlik kaygısından etkilenmediğini doğrulamak amacıyla Kozan (1984) tarafından geliştirilmiş olan Sosyal Beğenirlik Ölçeği kullanıldı. Ölçek doğru - yanlış şeklinde işaretlenen toplam 20 maddeden oluşmakta olup, 8 madde yanlış, 12 madde ise doğru olarak değerlendirmeye alınmaktadır. Katıımcılar sosyal beğenirlik yönünde verdiği her yanıt için bir puan almaktadır. Puanlar $0-20$ arasında değişmekte olup yüksek puan sosyal beğenirlik eğiliminin yüksek olduğuna işaret etmektedir.

Ölçeğin Kozan (1984) tarafından yapılan güvenirlik ve geçerliğinin ön incelemesinde, iç tutarlılığı 0.76, test - tekrar test değeri ise 0.91 olarak bulundu. Geçerlik için ölçek ile MMPI alt testleri arasındaki ilişkiden elde edilen korelasyon değerleri, Marlowe Crowne'ın ölçeği ile MMPI arasındaki korelasyon değerlerinin karşılaştırılmasıyla saptandı. Sonuçların paralel bulunması ölçeğin geçerliğinin olduğuna yönelik bir kanıt olarak sunuldu.

İşlemler: CHAÖ'nin Türkçe'ye uyarlaması ve kullanılması için Seth C. Kalichman'dan elektronik posta ile yazılı izin alındı ve ardından makalenin yazarı tarafından ölçek maddeleri Türkçe'ye çevrildi. Yapılan ölçek çevirisi konu ile ilgili çalışmalar yapan sosyal bilimci üç profesör tarafından kontrol edildi ve düzeltmeler yapılarak orta yol bulundu. Son olarak bir dilbilimci tarafından Türkçe ölçeğin İngilizceye geri çevirisi yapıldı.

Ölçekler katılımcılara Ankara'da üniversite öğrencilerinin sıklıkla uğradığı kafelerde uygulandı. Araştırmacı, gönüllü katılımcılara anket şeklindeki ölçekleri uygulamaya başlamadan önce çalışmanın amacına ilişkin kısa açıklamada bulundu, ardından ölçeklerin uygulanması sırasında nelere dikkat etmeleri gerektiği anlatıldı. Katılımcıların sözlü onamları alındıktan sonra uygulamaya başlandı. Uygulama yaklaşık 20 dakika sürdü. Elde edilen veriler SPSS ver. 15 paket programı kullanılarak çözümlendi. 


\section{BULGULAR}

\section{Güvenirlik}

CHAÖ'nin güvenirliği için alfa iç tutarlılık katsayısına, madde toplam ölçek korelasyonu değerlerine ve iki yarım güvenirlik katsayısı değerine bakıldı. Ölçeğin Cronbach Alfa değeri 0.835 olarak bulundu. Bu değer ölçeğin yazarının (Kalichman ve Rompa, 1995) bulduğu iç tutarlılık katsayısından biraz daha yüksektir. Ölçeğin 4. maddesi olan “Ilişkiye girdiğim kişiler büyük bir olasılıkla benim risk eğilimli olduğumu düşünmektedirler" maddesinin madde - toplam ölçek korelasyonu 0.238 olarak bulundu. $\mathrm{Bu}$ maddenin ölçekten çıkarılmasına karar verildi. Ölçekte kalan 10 maddenin yeniden alfa değerine bakıldığında ise bu değerin 0.84 'e yükseldiği görüldü. 0.84 alfa değeri yüksek derecede güvenirliğe işaret etmektedir. Ölçeğin iki yarım güvenirlik katsayısı ise 0.72 olarak bulundu. Ölçeğin güvenirlik değerlerinin kabul edilebilir düzeylerde olduğuna karar verildi.

\section{Geçerlik}

Ölçeğin Yapı Geçerliği: CHAÖ'nin yapı geçerliğini incelemek amacıyla açıklayıcı faktör analizi, $t$ testi ve Pearson korrelasyonları uygulandı. Ölçeğin verilerinin homojen ve faktör analizi yapıımasına uygunluğu incelenmiş, verilerin homojen olduğu ve varyansların faktör analizi yapılmasına uygun olduğu saptanmıştır (Kaiser-Meyer-Olkin katsayı değeri 0.867, Bartlett Küresellik Testi $533.96 p=0.000$ ). Verilere temel bileşenler faktör analizi, döndürme olarak dik döndürme Quartimax uygulandı (Tablo 1). Yapılan analiz sonucunda, özdeğeri 1'in üzerinde olan iki faktör tespit edildi. Ancak Scree Plot grafiğine bakıldığında grafiğin bir noktada belirgin ve sert bir şekilde kırıldığı görüldü. 10. madde dışındaki tüm maddelerin yüklerinin birinci bileşen üzerinde olduğu, 10. maddenin 1. ve 2. bileşen üzerindeki faktör yükleri arasında da belirgin bir fark olmadığından ölçeğin tek boyutlu homojen cinsel heyecan arama kişilik özelliğini ölçtüğüne karar verildi.

Yapılan analiz sonucunda, CHAÖ toplam puanları dikkate alındığında kadın ve erkek katıımcıların ölçekten aldıkları ortalama puanlar arasındaki farkın istatistiksel olarak anlamlı olduğu belirlendi ( $\mathrm{t}=4.21$, df: 181, $\mathrm{p}<.001$ ). Erkeklerin CHAÖ'nden aldıkları ortalama puanların $(X=25.11, S S=5.68)$ kadınlardan $(X=21.48, S S=5.82)$ anlamlı olarak yüksek olduğu bulgusu, literatür bulgularıyla (Kalichman ve Rompa, 1995; Gaither ve Selldom, 2003) tutarlılık göstermektedir. 
Tablo 1: Cinsel Heyecan Arama Ölçeğinin Faktör Yükleri

\begin{tabular}{|c|c|c|c|}
\hline & $F 1$ & $F 2$ & Madde \\
\hline \multicolumn{4}{|l|}{ F 1: } \\
\hline 1.Sınırsız çılgınca cinsel ilişkiyi severim & 733 & .038 & .617 \\
\hline \multicolumn{4}{|l|}{ 2.Cinsel ilişkiye girmede en önemli şey fiziksel } \\
\hline heyecandır. & .642 & -.173 & .479 \\
\hline 3.Kondomsuz cinsel ilişki duygusundan zevk alırım. & .514 & .057 & .419 \\
\hline \multicolumn{4}{|l|}{ 4. İş cinsel ilişkiye geldiğinde fiziksel çekicilik kişiyi ne } \\
\hline kadar iyi tanıdığımdan daha önemlidir. & .549 & .547 & .523 \\
\hline 5.Şehvetli insanların arkadaşlıklarından zevk alırım. & .748 & .133 & 659 \\
\hline \multicolumn{4}{|l|}{ 6.Birisinin benimle cinsel ilişkiye girmesini sağlamak için } \\
\hline tam olarak doğru sayılamayacak şeyler söylerim. & .539 & .441 & .471 \\
\hline 7.Yeni cinsel yaşantılar denemeyi severim. & .756 & .119 & .537 \\
\hline 8.Cinselliğimi keşfediyormuşum gibi hissederim. & .578 & -.479 & .665 \\
\hline \multicolumn{4}{|l|}{ 9.Yeni ve heyecan verici cinsel deneyimler ve duygular } \\
\hline yaşamayı severim. & .740 & -.120 & .365 \\
\hline \multicolumn{4}{|l|}{ F 2: } \\
\hline 10.Porno film izlemekten zevk alırım & .472 & .589 & .593 \\
\hline Özdeğerler & 4.15 & 1.04 & \\
\hline Açıklanan toplam varyans $(51.91)$ & 41.54 & 10.37 & \\
\hline
\end{tabular}

CHAÖ'nin ayırt edici geçerliğini ölçmek için, ölçeğin cinsel yolla bulaşan bir hastalık (hepatit, frengi gibi) tanısı alanları almayanlardan ayırt edip etmediğine bakıldı ve bunun için $t$ testi kullanıldı. Cinsel yolla bulaşan bir hastalık tanısı alanlarla $(X=27.50, S S=4.50)$ almayanların ( $X=23.39$, SS $=6.00)$ CHAÖ puanları arasındaki fark anlamlı bulundu ( $t=2.13, d f=181, p<.05)$. Cinsel yolla bulaşan bir hastalık tanısı alanların CHAÖ puanlarının tanı almayanlardan anlamlı olarak daha yüksek olduğu görüldü. 
Tablo 2: Cinsel Heyecan Arama ile Riskli Cinsel Davranış Arasındaki Bağıntılar

\begin{tabular}{ll}
\hline Riskli Cinsel Davranış & Cinsel Heyecan Arama Toplam Puanı \\
\hline Son 12 ayda tek gecelik cinsel ilişki. & $.479^{* \star}$ \\
Birden fazla kişiyle aynı dönemde cinsel ilişki. & $.435^{\star *}$ \\
Toplam cinsel ilişkiye girilen kişi sayısı. & $.406^{\star \star}$ \\
Cinsel ilişkiden önce alkol kullanma sıklığı. & $.309^{\star *}$ \\
Cinsel ilişkiden önce yasadışı uyuşturucu madde kullanma sıklığı. & $.325^{* *}$ \\
\hline $\mathrm{p}^{* *}<0.01$ &
\end{tabular}

CHAÖ'nin geliştirme makalelerinde (Kalichman vd., 1994; Kalichman ve Rompa, 1995), cinsel heyecan arama bir kişilik özelliği olarak kabul edilmiş, korunmasız cinsel ilişkilerle ve cinsel ilişkiye girilen kişi sayısıyla bağıntılı olduğu saptanmıştı. Ölçeğin karşıt cinsel üniversite öğrencileriyle yapılan geçerlik çalışmasında (Gaither ve Selldom, 2003) ise CHAÖ, her iki cinsiyet için de toplam riskli cinsel davranış sayısıyla en güçlü korelasyonu göstermişti. Bu nedenle CHAÖ toplam puanlarının hangi riskli cinsel davranış ile ilişkili olduğu saptanmaya çalışıldı ve bunun için Cinsel Risk Alma Ölçeği (Stulhofer vd., 2009) maddeleri kullanıldı. Türkçe CHAÖ toplam puanları bu maddelerden tek gecelik cinsel ilişki sıklığıyla, birden fazla kişiyle aynı dönemde cinsel ilişki sıklığıyla, bireyin tüm hayatı boyunca cinsel ilişkiye girdiği kişi sayısıyla, cinsel ilişkiye girmeden önce alkol ve yasa dışı uyuşturucu madde kullanma sıklığıyla bağıntılı bulundu (Tablo 2). Türkçe CHAÖ ile kondom kullanmayı ölçen cinsel risk alma maddeleri arasında ise Kalichman ve Rompa (1995)'dan farklı olarak herhangi bir bağıntı bulunmadı.

Katılımcıların yanıtlarının sosyal beğenirlik kaygısından etkilenip etkilenmediğini sınamak için ölçekle aynı anda "Sosyal Beğenirlik Ölçeği" uygulandı. CHAÖ toplam puanları sosyal beğenirlik puanları ile herhangi bir korelasyon göstermedi. CHAÖ ile riskli cinsel davranış arasındaki korelasyonların sosyal beğenirlikten etkilenmediği görüldü. $\mathrm{Bu}$ sonuçlar bize katılımcıların CHAÖ'ndeki maddeleri sosyal beğenirlik kaygısından etkilenmeden samimiyetle yanıtladıkları konusunda bilgi verdi ve geçerliğe katkı sağladı.

\section{TARTIŞMA}

CHAÖ'nin toplumumuzda geçerlik ve güvenirliğini sınayan bu çalışma, bilgilerimize göre bir ilk çalışma niteliğindedir. Bu çalışma ile 
cinsel davranışla bağıntılı HIVIAIDS riskini ölçmekte kullanılan CHAÖ'nin karşıt cinsel yönelimli bir grup Türk üniversite öğrencisinde geçerlik ve güvenirliğinin araştırıması amaçlanmıştır. Yapılan analizler sonucunda Türkçe CHAÖ'nin orijinal ölçekle (Kalichman ve Rompa, 1995) benzer bir şekilde Türk üniversite öğrencilerinde riskli cinsel davranışları yordamada kullanılabilecek güvenilir ve geçerli görünen bir ölçme aracı olduğu sonucuna varıldı.

Bulunan sonuçlar Türkçe CHAÖ'nin yüksek iç tutarlılığı, yeterli iki yarım güvenirliği ve madde - toplam ölçek korelasyonu olduğunu gösterdi. İç tutarlııı katsayısı, 4.maddenin madde - toplam ölçek korelasyonunun düşük olması nedeniyle ölçekten çıkarılmasından sonra geride kalan 10 madde için 0.84 olarak bulundu. Bu değer Kalichman ve Rompa (1995)'nın eşcinsel örnekleminde bulduğu 0.79 ve şehirde yaşayan düşük gelirli karşıt cinsel yetişkin örnekleminde bulduğu 0.81 değerlerinden biraz daha yüksektir. Gaither ve Selldom (2003) ise üniversite öğrencilerinde ölçeğin alfa iç tutarlılık değerlerini kadınlar için 0.81 , erkekler için ise 0.83 olarak buldular. Türkçe CHAÖ'nin homojen - tek boyutlu olması nedeniyle de (Şeker ve Gençdoğan, 2006) iki yarım güvenirlik değerine bakıldı ve yeterli seviyede bulundu. Bulgular doğrultusunda Türkçe CHAÖ'nin iç tutarlılığının yüksek olduğuna ve güvenirlik değerlerinin genel olarak yeterli seviyede olduklarına karar verildi.

Ülkemizde yapılan cinsellikle bağıntılı AIDS araştırmalarında temel olarak katılımcıların HIVIAIDS konusundaki genel bilgileri ölçülmekte ve AIDS bilgi ölçeklerinden yaralanılmaktadır. Fakat HIVIAIDS bilgileri yeterli seviyede olmasına rağmen bazı bireyler riskli cinsel davranışlarını sürdürme eğilimindedirler. AIDS'in cinsellikle bağıntılı davranışsal boyutuyla ilgili psikolojik değişkenleri de içine alan çalışmaların ülkemizde oldukça sınırlı sayıda yapılması nedeniyle bu çalışmada benzer ölçek geçerliğine bakılmadı.

Ölçeğin faktör yapısını ortaya koymak amacıyla açıklayıcı faktör analizi yapıldı. Yapılan analiz sonucunda Türkçe CHAÖ'nin açıkladığı toplam varyans değerinin yeterli seviyede olduğu ve madde yüklerinin büyük oranda birinci bileşen üzerinde olması nedeniyle de tek boyutlu olarak kabul edilmesine karar verildi. Orijinal makalede (Kalichman ve Rompa, 1995) faktör analizi sonuçları verilmediğinden bulunan sonuçlar ile kıyaslama yapılamadı.

Erkek katılımcıların CHAÖ ortalama puan değerleri $(X=25.11$, $S S=5.68)$ kadınların ortalama değerlerinden $(X=21.48, S S=5.82)$ anlamlı olarak daha yüksek bulundu. Bu bulgu üniversite öğrencileri 
örnekleminde CHAÖ kullanılarak yapılmış olan diğer çalışmaların sonuçlarıyla tutarlılık göstermektedir (Arnold vd., 2002; Gaither ve Selldom, 2003; Gullette ve Lyons, 2005). Bu sonuç aynı zamanda Zuckerman (2007)'ın heyecan arama kuramıyla da uyumludur.

Ayırt edici geçerlik çalışması kapsamında Türkçe CHAÖ'nin cinsel yolla bulaşan hepatit, frengi gibi bir hastalık tanısı alanlarla almayanları ayır etme yeteneğine bakıldı ve bunun için $t$ testi uygulandı. Cinsel yolla bulaşan bir hastalık tanısı alanların CHAÖ'nden aldıkları puan ortalaması $(X=27.50, S S=4.50)$ tanı almayanların ölçekten aldıkları puan ortalamasından $(X=23.39, S S=$ 6.00) anlamlı olarak yüksek bulundu. Bu sonuç da ölçeğin yapı geçerliğine katkı sağladı.

Kalichman ve Rompa (1995)'nın yaptıkları gibi Türkçe CHAÖ'nin hangi riskli cinsel davranışlar ile bağıntılı olduğuna bakıldı. Kalichman ve Rompa, heyecan arama kuramıla tutarlı olarak, CHAÖ ile cinsel ilişkiye girilen kişi sayısı ve korunmasız cinsel ilişki sıklığı arasında doğru orantılı bir bağıntı bulmuşlardı. Türkçe CHAÖ ise cinsel ilişkiye girilen kişi sayısını ölçen maddeler olan "Son 12 aydaki tek gecelik cinsel ilişki" $\left(r=0.479 ; p^{* *}<0.01\right)$, "Birden fazla kişiyle aynı dönemdeki cinsel ilişki" $\left(r=0.435 ; p^{* *}<0.01\right)$ ve "Toplam cinsel ilişkiye girilen kişi sayısı" $\left(r=0.406 ; p^{* *}<0.01\right)$ maddeleriyle orta düzeyde doğru orantılı bir bağıntı gösterdi. Bulunan bu sonuçlar literatür ile uyumluluk göstermektedir. Gaither ve Selldom (2003) ise üniversite öğrencileriyle yaptıkları çalışmada CHAÖ'ni toplam cinsel eylem sayısıyla en güçlü şekilde ilişkili bulmuşlardır. Henderson ve arkadaşları (2005) ise yüksek heyecan arama ile vajinal yolla cinsel ilişkiye girme arasında doğru orantılı ve anlamlı bağıntı bulmuşlardır.

Türkçe CHAÖ "Cinsel ilişkiden önce alkol kullanma sıklığı" ( $r=$ 0.309; $\left.p^{* *}<0.01\right)$ ve "Cinsel ilişkiden önce yasadışı uyuşturucu madde kullanma sıklığı" $\left(r=0.325 ; p^{* *}<0.01\right)$ gibi cinsel risk maddeleriyle de doğru orantılı bir bağıntı gösterdi. Kalichman ve Cain (2004), heyecan aramanın alkol kullanma ve cinsel risklerle ilişkili olduğunu, fakat heyecan aramanın alkol kullanma ve riskli cinsel davranış arasındaki ilişkiyi açıklamadığını belirtmiş̧erdir.

CHAÖ puanları ile kondom kullanma ile ilgili cinsel risk maddeleri olan "Illk cinsel ilişkide kondom kullanma", "Son cinsel ilişkide kondom kullanma" ve "Son 12 ay içerisinde girilen cinsel ilişkilerde düzenli kondom kullanma" maddeleri arasında herhangi bir bağıntı bulunmadı. Karşıt cinsellerde CHAÖ puanları ile kondom kullanma 
arasında karışık bulgular mevcuttur. Bazı araştırmacılar yüksek CHAÖ puanları ile kondom kullanmama arasında bağıntı bulurlarken (Arnold vd., 2002), bazıları ise CHAÖ ile ilişkilerde kondom kullanma maddeleri arasında herhangi bir anlamlı bağıntı bulmamışlardır (Martinez vd., 2007).

$\mathrm{Bu}$ çalışma tamamen katılımcıların kendi bildiriminden toplanan veriler kullanılarak yapıldığından, bulunan sonuçlar yorumlanırken olası yanlı yanıtlar hesaba katılmalıdır. Yapılan çalışmanın cinsellikle bağlantılı olması ve cinsellikle ilgili soruların Türk toplumunun büyük bir kısmında hassas karşılanması nedeniyle, katılımcılara aynı zamanda Sosyal Beğenirlik Ölçeği uygulandı. Fenton vd. (2001)'nin belirttikleri gibi, cinsel davranış büyük oranda özel etkinlik olup, değişen derecelerde sosyal, kültürel, dini, ahlaki ve hukuki norm ve sınırlamalara bağlıdır. Yapılan çalışmanın sosyal beğenirlik kaygısından etkilenmediği sonucuna ulaşıldı.

\section{SONUÇ VE ÖNERILER}

Çalışmada, bulgular doğrultusunda Türkçe CHAÖ'nin iç tutarlılığının yüksek olduğu ve güvenirlik değerlerinin genel olarak yeterli seviyede olduğu tespit edilmiştir. Bundan sonra yapılacak çalışmalarda ise AIDS riski taşıyan gruplardan olan eşcinseller üzerinde CHAÖ'nin geçerlik ve güvenirlik çalışmasının yapılması yararlı olacaktır. 


\section{KAYNAKLAR}

Arnold, P., Fletcher, S. and Farrow, R. (2002). Condom use and psychological sensation seeking by college students. Sexual and Relationship Therapy, 17, 355-365.

Ay, P.and Karabey, S. (2006). Is there a 'Hidden HIVIAIDS epidemic'in Turkey? : The gap between the numbers and the facts. Marmara Medical Journal, 19, 90-97.

Bancroft, J., Janssen, E., Carnes, L., Goodrich, D. and Strong, D. (2004). Sexual activity and risk taking in young heterosexual men: The relevance of sexual arousability, mood, and sensation seeking. The Journal of Sex Research, 41, 181-192.

Çok, F., Gray, L.A. and Ersever, H. (2001). Turkish university students'sexual behavior, knowledge, attitudes and perceptions of risk related to HIVIAIDS. Culture, Health and Sexuality, (3). 8199.

Duyan, V. (2006). HIV infeksiyonunda sosyal hizmetler ve danışmanlık. Güncel Bilgiler Işığında HIVIAIDS. (Edit. S. Ünal ve A. Tümer), s. 291 - 304. Bilimsel Tıp Yayınevi, İstanbul.

Fenton, K.A., Johnson, A.M., McManus, S. and Erens, B. (2001). Measuring sexual behavior: methodological challenges in survey research. Sexually Transmitted Infections, 77, 84-92.

Gaither, G.A. and Selldom M. (2003). The sexual sensation seeking scale: Reliability and validity within a heterosexual college student sample. Journal of Personality Assessment, 81, 157-167.

Gullette, D.L. and Lyons, M.A. (2005). Sexual sensation seeking, compulsivity, and HIV risk behaviors in college students. Journal of Community Health Nursing, 22, 47-60.

Hendershot, C.S., Stoner, S.A., George, W.H. and Norris, J. (2007). Alcohol use, expectancies, and sexual sensation seeking as correlates of HIV risk behavior in heterosexual young adults. Psychology of Addictive Behaviors, 21, 365-372.

Henderson, V.R., Hennessy, M., Barrett, D.W., Curtis, B., Roth, M.M., Trentacoste, N. and Fishbein, M. (2005). When risky is attractive: sensation seeking and romantic partner selection. Personality and Individual Differences, 38, 311-325.

Hoyle, R. H., Fejfar, M. C. and Miller, J. D. (2000). "Personality and sexual risk taking: A quantitative review," Journal of Personality, 68, 1203-1231. 
Kalichman, S.C. and Cain, D. (2004). A prospective study of sensation seeking and alcohol use as predictors of sexual risk behaviors among men and women receiving sexually transmitted infection clinic services. Psychology of Addictive Behaviors, 18, 367-373.

Kalichman, S.C., Heckman, T. and Kelly, J.A. (1996). Sensation seeking as an explanation for the association between substance use and HIV- related risky sexual behavior. Archieves of Sexual Bahavior, 25, 141-154.

Kalichman, S.C. and Rompa, D.(1995). Sexual sensation seeking and sexual compulsivity scales: Reliability, validity, and predicting HIV risk behavior. Journal of Personality Assessment, 65, 586-601.

Kalichman, S.C., Johnson, J.R., Adair, V., Rompa, D., Multhauf, K. and Kelly, J.A. (1994). Sexual sensation seeking: Scale development and predicting AIDS- risk behavior among homosexually active men. Journal of Personality Assessment. 62, 385-397.

Kozan, K. (1984). Davranış bilimleri araştırmalarında sosyal beğenirlik boyutu ve Türkiye için bir sosyal beğenirlik ölçeği. ODTÜ Geliştirme Dergisi, 10, 447-477.

Martinez, O.G., Bermudez, M.P., Teva, I. and Casal, G.B. (2007). Sexual sensation- seeking and worry about sexually transmitted diseases (STD) and human immunodeficiency virus (HIV) infection among Spanish adolescents. Psicothema, 19, 561-666.

Nielsen, S. and Lazarus, J.V. (2006). HIVIAIDS in Europe. (Ed. S.Matic, J.V.Lazarus and M.C.Donoghoe). World Health Organization Europe. Denmark.

Şeker, H. ve Gençdoğan, B. (2006). Psikolojde ve eğitimde ölçme aracı geliştirme. (1.baskı). Ankara: Nobel Yayın Dağıtım.

Stulhofer, A., Graham, C., Bozicevic, I., Kufrin, K. and Ajdukovic, D. (2009). An assessment of HIV/STI vulnerability and related sexual risk- taking in a nationally representative sample of young Croatian adults. Archieves of Sexual Behavior, 38, 209 - 225.

Zuckerman, M. (2007). Sensation seeking and risky behavior. Washington: American Psychological Association.

Zuckerman, M., Eysenck, S. and Eysenck, H.J. (1978). Sensation seeking in England and America: Cross- cultural, age, and sex comparisons. Journal of Consulting and Clinical Psychology, 46, 139 - 149.

Zuckerman, M., Kolin, E.A., Price, L. and Zoob, I. (1964). Development of a sensation seeking scale. Journal of Consulting Psychology, 28, 477 - 482. 